\title{
Current Situation of Practical Teaching for Undergraduate Visual Communication Specialty and its Measures
}

\author{
Pingping Yang \\ Yantai Nanshan University \\ Yantai, China
}

\begin{abstract}
To strengthen art and design practice and improve the quality of talents cultivation, the education for visual communication specialty in colleges must be marketoriented, and build a sound professional practical teaching system, enhance students' comprehensive competitiveness to achieve the goal of cultivating advanced composite talents who are innovative with agile minds and unique insights.
\end{abstract}

Keywords-visual communication specialty; practical teaching; teaching

\section{Study ON DOMESTIC CURRENT SituATION OF THE Visual COMMUNICATION PRACTICAL TEACHING OPERATION}

\section{A. Operation of Practical Teaching Require a Stable Project Support}

The target positioning for undergraduate students specialized in visual communication of higher education is "to cultivate students into the ones with certain basic cultural knowledge and expertise theory, technology capability, practical operating skills and good professional quality". As an important part of teaching organization for visual communication design specialty, practical teaching of visual communication accounts for quite a large proportion of the teaching plan. Currently, visual communication design specialty has a different mode of practical teaching which can be divided into virtual projects, competition projects, actual commercial projects and outside school practical projects.

However, insufficient and instable supply of actual projects exists in the practical teaching process of visual communication with the reasons as below:

- Social reputation and appeal of practical project design haven't been established.

- Practical teaching projects and professional practice curriculum setting cannot integrate and operate organically.

\section{B. Problems Exist in Operating Cycle of Visual Communication Practical Teaching}

1) Contradictory between practical teaching operating cycle and the cycle of competition projects: The visual communication design competitions that are more formal and influential are mainly held in the first half year, and even some competitions are not held every year, for example the National College Students Advertising Art Competition with index significance is held every two years. Virtual project is common in practical teaching but with no other choice. Virtual project may meet the basic needs of teaching, and attain a certain practical teaching purpose through completing such segments as "design type cognition", "creative design", "creative realization" and "project summary". However, we cannot realize "design research", "design feedback", "design submission" and others through import of a virtual project. And it is very important for a commercial project as it is directly related to the correctness of design direction, perfection of the design idea and design integrity etc. Virtual practical teaching is unable to meet professional requirements without adding the companies and commercial factors.

2) Contradictory between practical teaching cycle and the actual commercial project cycle: Besides the lack of project stability, practical teaching also has the problem of contradictory between teaching cycle and actual commercial project cycle. One of the significant characteristics of actual commercial projects is its design cycle is very short, usually a general project is required to be settled in 2-3 weeks.

\section{Lack of Applicable Teaching Materials for Practical Teaching}

Practical teaching allows students to gradually master vocational skills required by the job, and to possess the comprehensive practical ability and quality within this specialty. But the general textbooks can not really meet the needs of practical teaching and it can not maintain a certain scientificity, systematicness and integrity, so ultimately they are unable to improve students' operation skills or to meet the requirements for skill training required by the specialty. 


\section{Problems Exist in Deployment Mode of Visual Communication Practical Teaching.}

The traditional "teacher-oriented type" of learning is facing great challenges as its neglect of students' personality has hindered effective reception of knowledge and the formation of innovative ideas. Professional practice course generally adopts the mode of exercising the questions or projects set by teachers. Namely, teachers provide material resources, and students shall accomplish the exercises or projects within a specified framework according to the teachers' ideas and requirements.

\section{SOLUTIONS}

\section{A. Establish Visual Communication Laboratory}

The laboratory for visual communication specialty includes a series of equipment and facilities from image acquisition to printout which is the primary try for students to apply theory into practice, and it is also an intermediate link connecting students' classroom learning and off-campus practice. Students shall be required to master necessary operating skills at the stage of learning in school, and to transfer the knowledge learned in classroom into practice to make a better digest of those knowledge, laying a solid foundation for entering into society and reducing the runtime with the society after graduation. At present, the construction of art and design laboratory in many of our colleges is in such sorrow situation, being a flaw in cultivation of talents specialized in design. As a result, educators of higher education must change their concept, strengthen laboratory construction, provide support and protection in funding and personnel, implement the laboratory management system strictly, facilitate the functioning of college laboratories, thus to provide students with good experimental conditions and environment.

\section{B. Broaden School-running Ways and Strengthen \\ Combination between School and Enterprise}

Combination between school and enterprise is an effective mode for practical teaching of design specialty and talent cultivation in colleges, and also an effective supplement to the insufficient construction of college laboratories. The "workshop" teaching conducted in Bauhaus Art School early in the 1920s has provided us with a good inspiration, namely to expand school-running ways and strengthen cooperation between school and enterprise, thus to create more and better opportunities for students to practice in enterprises. It has resolved the problem of cultivation of college student practice ability on the one hand, and on the other, it has helped enterprises in solving the problem of talent selection and reserves. In addition, the construction of college laboratories, no matter how comprehensive, will inevitably be subject to the influence and limitation of finance, manpower, equipment lagging behind and aging as well as others, and simultaneous development with the industry cannot be fully realized. Therefore, combination of school and enterprise is an effective supplement to the insufficient construction of college laboratories. At the same time, college education shall take the industrial development as a guidance, to focus on the needs of talent market, and take initiative to make reform and innovation in specialty setting, class hour arrangements, increasing and deleting of teaching contents, adjustment of teaching methods, thus to improve teaching quality and talent cultivation quality.

\section{Perfect the Workshop System}

Set up workshop reasonably in accordance with specific situation of existing teachers, and establish a relatively sound workshop system which is also a mode to cultivate students' practical ability. Workshop is the stage for teachers' professional development and expansion, but also a platform for students to exercise practical ability, adapt to the environment and achieve professional development. Currently, many colleges have quite a lot of their own characteristics in this aspect with obvious effect. However, macro-control shall be conducted for the workshop system of colleges, and strengthen management and guidance to such problems as teaching deviation, disguised exploitation and design property disputes, to make the workshop system achieve a virtuous cycle, thus to bring about benefits for both students and teachers.

\section{Strengthen Combat Training through Fixed Design Competition}

The enthusiasm of teachers teaching and students learning is an important factor for whether or not a course teaching is success, and competition is undoubtedly a good measure in improving the enthusiasm of teachers and cultivating of students' learning interest and creativity. Design competition can improve the vision of both teachers and students as they can learn from the design competition and compete while learning, which can consolidate students' knowledge structure on one hand, and on the other it can promote students to continue seek progress through selflearning, and improve their design capabilities. Thus, art and design education in colleges shall give policy and funding support and encouragement in this regard, establish a long lasting and effective incentive mechanism, and build a solid team of professional teachers. At the same time, it is an effective measure to enhance school image and establish a good reputation.

\section{E. Using Design Project Practice in Teaching}

The teaching of visual communication specialty shall not only pay attention to theoretical knowledge, but also need to stress actual practical skills. Design project practice may be adopted, that is to say teachers can design project practice assignments in combination with industrial development and typical design case on the basis of students' mastering of relevant theories. Students shall accomplish the project assignment through relevant social visits, research, lab operations discussion, project research and so on to train their capabilities of analysis, creation and design, including the ability to communicate with others and so on. Thus we should explore an effective path from issue raising and studying to solutions seeking, optimization and settlement to cultivate students' comprehensive practical ability. 


\section{F. Teaching System of Simulating Company Mode}

Currently, simulating company to teach is a teaching reform with new concept. In the simulation company, such positions as general manager, designer, planner, copy writer, salesman, budget officer, market investigator, construction engineer, financial manager, material controller and other positions are set, so that students may take turns to work in each position and to conduct role change, coordination and exchange in the fields of post distribution, production organization and marketing, thus to form a team. After a period of training, students will be able to become the technical talents in such aspects as project design, tender offer, material selection, construction technology, project management, project acceptance, project accounts. Students' habit ability will be trained through company simulation and role adaption, and the generation of innovative idea and team cooperation will be realized through brainstorming and other sectors.

\section{G. Establish Multi-channel Design Practice and Teaching Mode both Inside and Outside School}

Teaching modes of design practice involves many aspects, besides the above mentioned, colleges still need to build more and wider approaches to provide students with practice conditions as many as possible. For example, the undertaking of research and development of corporate design projects requires high requirement of the actual design level of college teachers as well as the students. Another example, lead the students to achieve self-employment in combination with specialty features. I have led students to conduct indepth investigation of tourist souvenir market and manufacturers in Chongqing and various regions to make tourism souvenir design with characteristic culture, which can lead the students to participate in various competitions on one hand, and on the other, a considerable number of students may rely on this platform to cooperate with manufacturers to design and produce, thus to realize selfemployment.

\section{CONCLUSION}

With the continuous development of modern educational science and the constant update of educational contents and means, practical teaching has increasingly become an important part for full implementation of quality education, cultivation of students' practical skills, creative ability as well as scientific and technological quality, and it is an indispensable segment in teaching which cannot be replaced by any other teaching method. Therefore, the study of practical teaching is of important significance for the teaching of visual communication within undergraduate program.

\section{REFERENCES}

[1] Liu Ben. Construction of Practical Teaching System for Visual Communication Specialty[J]. Education Review, 2014,09:12-18

[2] Zou Baofeng. Discussion on the Role of Practical Teaching in Visual Communication Design[J]. Northern Literature, 2012
[3] Jin Yijun. Study on Practical Teaching in Cultivation of Visual Communication Talents[J]. Modern Enterprise Education, 2012,12

[4] Zhai Chenxi, Liang Le, Wang Ruoyu and Yang Yunjie. Primary Study on College Elite Education Reform [M] 